\title{
Impacts of Free Trade Agreement on US State Vegetable and Fruit Trade Flows
}

\author{
David Karemera \\ South Carolina State University \\ Paul Reinstra-Munnicha \\ South Carolina State University \\ Joseph Onyeocha \\ South Carolina State University
}

\begin{abstract}
A few studies have shown that free trade agreements have affected the pattern of state exports. This paper examines the effects of free trade agreements on US state vegetable and fruit trade flows. We propose a single commodity gravity equation to overcome a common shortcoming of most gravity models, which are applied to aggregate trade flows. Our results show significant gross trade creation effects of NAFTA and APEC that are greater than the EU gross trade creation effects. In addition, our findings reveal that the Asian Pacific Rim region is a significant destination of many vegetables and fruits from US states.
\end{abstract}

- JEL Classification : F13, F14, F15

- Key Words: international trade, gravity models, free trade agreements, vegetables

\footnotetext{
*Corresponding address: David Karemera: South Carolina State University, Orangeburg, SC 29117 USA, Tel: 803536 7136, e-mail: Karemera@scsu.edu, Paul Reinstra-Munnicha: South Carolina State University, Orangeburg, SC 29117 USA, Tel: 803 5368456, e-mail: Prienstr@scsu.edu, Joseph Onyeocha:South Carolina State University, Orangeburg, SC 29117 USA, Phone : 8035368457, e-mail: jonyeocha@scsu.edu

(2009-Center for International Economics, Sejong Institution, Sejong University, All Rights Reserved.
} 


\section{Introduction}

The gravity theory continues to be debated in terms of theoretical foundation, but there is now a substantial body of literature, including work by Anderson (1979), Bergstrand (1985, 1989, and 1990), and Markusen (1986) that theoretically justify the use of gravity equations. Particularly, Bergstrand (1985) utilizes consumer and producer maximization approaches to generate a gravity equation similar to Linneman (1966)'s empirical equation. In a gravity model, factors affecting trade flows between two trading countries such as their incomes, distance between them and other natural or artificial factors are trade determinant factors. Bergstrand (1989) expands the gravity equation to incorporate differences of relative factor endowment and non-homothetic preferences. Deardorff (1998) has found that it is possible to derive a gravity equation straightforward from Heckscher-Ohlin foundations as well as trade models that rely on differentiated products. Anderson and van Wincoop (2003) estimated a structural version of theoretical gravity model with inter-regional trade and commodity flow model developed by Anderson (1979).

The empirical application and great success of gravity models are widely acknowledged (Hummels and Levinsohn, 1995). Empirically, the gravity models describe the bilateral trade flows as a log-linear function of economic and physical size (GDP and population) and of transaction cost (distance and adjacency) between two trading countries. The models contain the following three types of variable components: 1) economic factors affecting trade flows in origin country; 2) economic factors affecting trade flows in destination countries; and 3) natural or artificial factors enhancing or restricting trade flows. Two appealing reasons for the success are: 1) empirical estimation produces a well fitting regression; and 2) the models imply a parsimonious interpretation of robust econometric estimates. Numerous studies applied the gravity models to examine an impact of economic integration to trade flows among integrating countries. Gould (1998) used a gravity model approach in determining how NAFTA has affected the growth of North American trade over 1980-1996. His empirical results support the impacts of NAFTA on trade. ${ }^{1}$ Krueger (1999a, 1999b) also used gravity equations but found little evidence indicating that trade patterns had been significantly altered by

${ }^{1}$ Burfisher et al. (2001) provide a survey of the impact of NAFTA on the United States and topic covers both macroeconomic issues and structural adjustments. 
NAFTA. ${ }^{2}$ Using the gravity model, Frankel et al. (1995) discovered evidence of trading blocks in the European Community.

A common shortcoming of most gravity models is that the models are derived and applied to aggregate commodity trade flows; thus, they assume that the trade effects are uniform across individual commodity trade flows. In addition, most previous studies that used gravity models have focused on the impacts of trade policy changes at national levels. For example, while a free trade policy may be a national policy, its impact may not be uniform across states or regions. There are studies that have applied gravity models in analyzing regional trade impacts of NAFTA, but their focuses were on manufactured goods and aggregated data (Coughlin and Wall, 2002, and Wall, 2000). In analyzing agricultural trade flows, it is important to take into account trade impacts on individual commodity trade flows by using regional/state level data since different regions within a country have naturally differing resources endowments and differing supports of exports and imports activities. Furthermore, the outputs of agricultural commodities such as vegetable and fruit are dependent on local weather, agricultural land, and other natural resources which are site specific.

While trade flows are generally determined on the basis of the principle of comparative advantage (lowest marginal cost of production) in a preferential trade system, presently, it is not clear whether state trade flows of vegetable and fruit may be enhanced or distorted by various integration schemes and/ or government interventions. Moreover, the determinants of trade flows of vegetable and fruit commodities and their economic effects are not clearly known. The objective of this paper is to examine the factors affecting the trade flows, and evaluate the effects of regional trade agreements on state vegetable and fruit trade flows.

Following the generalized gravity model by Bergstrand $(1985,1989)$, we propose and apply the single gravity equation to analyze trade flows of an individual commodity for nine selected commodities of vegetable and fruit and provide comparative static of the effects of factors aiding or resisting vegetable and fruit trade flows. The traditional gravitational variables are augmented with variables reflecting regional preferential trade agreements such as the NAFTA, the European Union (EU), and Asian-Pacific Economic Cooperation (APEC). We use

\footnotetext{
${ }^{2}$ She pointed out that her conclusion is tentative because of the following reasons: 1 ) it is difficult to separate economic behavior into pre-NAFTA and post-NAFTA; 2) the agreement called for a 10-to15year phase-in of the tariff cuts for many commodities; and 3) NAFTA can be viewed as another step in the process of Mexican trade liberalization.
} 
U.S. state level data from 1996 to 2002 for nine commodities of vegetable and fruit that are most often traded by the U.S. states to determine economic and non economic factors affecting their flows

The remainder of the paper is organized as follows. Section II presents an empirical framework that is based on the modification of theoretical gravity model. Section III describes data sources and the empirical results. Section IV concludes the paper.

\section{Empirical Specification of Commodity Specific Gravity Models}

The complete specification of the single commodity gravity equation is provided in Bergstrand $(1985,1989)$ and additional details and application are available in Koo and Karemera (1993), and Karemera et al. (1999).

Following specifications by Bergstrand (1985 and 1989), Koo and Karemera (1993), Karemera et al. (1999), Xinpeng (2000), and Anderson and van Wincoop (2003), we use a reduced form specification, and modify the traditional gravity equation to capture the following key factors. Traditional gravity models include national income of trading countries, their respective population and distance between the trade partners. In our empirical models, the free trade variables NAFTA, APEC, and EU are included to examine whether these factors aiding or resisting trade flows in terms of gross trade creation effects. The distance $d_{i j}$ is used to represent transport cost. The adjacency dummy variable $A_{i j}$ is included in the empirical model. It is hypothesized that there is more trade between countries with common borders than countries without common borders or geographically farther apart. Thus, our empirical commodity specific gravity model of trade is specified as:

$$
\begin{aligned}
& X_{i j}= B Y_{l}^{\beta 1} Y_{j}^{\beta 2} d_{i j}^{\beta 3} N_{i}^{\beta 4} N_{j}^{\beta 5} E_{i j}^{\beta 6} \times \\
& \exp \left[\beta_{7} A_{i j}+\beta_{8} N A F T A_{j}+\beta_{9} A P E C_{j}+\beta_{10} E U_{j}+\beta_{11} S E R_{i j}\right] \varepsilon_{i j} \\
& i=1, \ldots, N_{1} \text { and } j=1, \ldots N_{2}
\end{aligned}
$$

where

$X_{i j}=$ the amount of U.S. state $i$ 's particular commodity imported by country $j$;

$Y_{i}=$ the gross state farm product for U.S. state $i$;

$Y_{j}=$ the gross domestic product of the importing country $j$;

$N_{i}=$ the population of U.S. state $i$;

$N_{j}=$ the population of the importing country $j$;

$d_{i j}=$ the shortest distance between U.S. state $i$ 's commercial centers and the 
importing country $j$ 's import port;

$E_{i j}=$ the spot exchange rate (country $j$ 's currency in terms of the U.S. dollar);

$A_{i j}=$ the border or adjacency dummy variable that takes value 1 if the U.S. state $i$

and the importing country $j$ share a land border and 0 otherwise;

$N A F T A_{i j}=$ the dummy variable equals 1 to identify intra-NAFTA trade for

state $i$ exports to Canada or Mexico and 0 otherwise;

$A P E C_{i j}=$ The dummy variable used to identify exports to the APEC countries.

It equals 1 for state $i$ exports to APEC countries and 0 otherwise;

$E U_{i j}=$ dummy variable used to identify exports to EU countries. It equals to 1

for state $i$ exports to EU countries and 0 otherwise;

$S E R_{i}=$ dummy variable used to identify exports from the southeast region. It

equals 1 if exports are from the SER and 0 otherwise;

$\varepsilon_{i j}=$ the error term.

We use EC dummy for the periods of 1997 and 1998, and EU is used for the years 1999-2001. In order to identify the impact of the NAFTA, a NAFTA dummy variable was included to identify trade flows between any two NAFTA countries. This variable reflects gross trade creation effects arising from the NAFTA integration scheme. Similarly, we also include APEC dummy variable to capture gross trade creation effects arising from the APEC integration scheme. It is hypothesized that economic integrations or free trade arrangements under NAFTA, APEC, and/or EU would enhance trade flows among member countries generating gross trade creation effects.

An attempt was made to determine whether the Southeast Region (SER) of the United States, SER was a significant source of vegetable and fruit trade flows. A regional dummy variable, SER, is introduced to identify differential factors affecting trade flows from the SER. It can be argued that regional trade effects of NAFTA are different among all sub-national regions within a trading country. The differences arise to reflect differences in infrastructure that supports and promotes state export activities. Furthermore, location and geography may play a role in supporting export promotion and trade activities.

Traditional gravity models typically use gross domestic product (GDP) to represent the income variable as in Linneman (1966) and Bergstrand (1985 and 1989). However, we use total farm income rather total GDP since it is the variable most closely related to vegetable production. Thus, total farm income in exporting U.S. states is used to represent production and export capacity of sending states 
(see Koo et al. (1993) for details and statistics justification). With respect to importing countries, the importing country's income is represented by its GDP and reflects its purchasing power and absorption capacity.

It is expected that $\beta_{2}, \beta_{5}, \beta_{6}, \beta_{7}, \beta_{8}, \beta_{9}, \beta_{10}$, and $\beta_{11}$ have positive coefficient signs while the coefficient estimates of $\beta_{3}$ and $\beta_{4}$ are expected to be negative. Note that the estimated coefficient signs for $\beta_{l}$ might have an undetermined sign since we use total farm income, instead of using total GDP. The actual sign could reflect the importance of the selected commodity in the state's commodity composition of trade. A rise in state farm income may reflect increased ability to export the commodity and would lead to increased trade flows under assumption of increased capital/labor ratio. Thus, it has an expected positive coefficient sign. However, in single commodity trade, an increase in farm income may also induce resource relocation to higher profit margin export goods leading to decreased exports of the particular commodity leading to a negative coefficient sign. A rise in income (total GDP) in an importing country represents an increase in the purchasing power; which leads to higher imports and the expected coefficient sign would be positive.

\section{Empirical Results}

\section{A. Data Sources}

Commodity data including exports, imports, and prices are obtained from World Trade Atlas of GTI Inc. under alternative Harmonized System Codes (HS Code) from 1996 to 2002. The data were pooled over 6 years to increase the degree of freedom. Table 1 lists all exporting U.S. state and countries of destination. Many importing countries are developing countries for which quarterly data are not available. To overcome the data limitations and obtain consistent data to capture seasonality effects, we statistically disaggregated yearly data into quarterly data using the Spline cubic method (Wolfram, 2006).

Table 2 shows the names of all commodities included in the analysis and the corresponding codes. Data for Agricultural Gross Domestic Product (GDP from the farm sector), population, inflation, are obtained from World Bank (WB) Development Indicators. Additional data such as GDP of importing countries and exchange rates are obtained from International Financial Statistics. State farm income of U.S. states is from USDA in various websites. Distance measure is obtained from Fitzpatrick and Modlin (1986) where they measured the great circle 
between largest cities (e.g., U.S. = New York).

\section{B. Estimation Results}

The model was estimated by the method of least squares for nine commodities. Our panel data exhibit a short time series and larger cross section units. We have eliminated sporadic trade flows and retained data consistent over time and cross section units. This procedure reduced the number of observations with high residual variance and increased the efficiency of the estimated coefficients of our empirical models. Our consistent data of cross section units did not exhibit serious heteroscedasticity problems, and the time effect is not estimable since available time series data points are less than the number of parameters in models. Thus, the usual method of least squares was used. Karemera et al. (1999) and Koo et al. (1993) offer detailed alternative estimation methods and discuss estimation issues.

Table 4 presents the estimated parameters of logarithmic transform of equation 1 for the selected nine vegetable and fruit trade flows. The $\mathrm{R}^{2}$ range from 0.37 to 0.08 and are typical of cross-section dominated series. The estimated coefficient models are significant and have expected signs in most models. Specification tests indicate that the models are adequate and suggest that free trade variables should be included in modeling vegetable and fruit trade flows (Koo and Karemera, 1993). Factors affecting trade flows and their effects are discussed below.

\section{(1) The Effects of Income, Population, and Exchange Rate}

Specification tests proposed by MacAleer (1985) suggest that GDP from the farm sector represents agricultural production capacity in exporting states, and disposable income represents purchasing power in the importing counties. The estimated coefficients are significant at the 5\% level and have the expected signs in most cases. This result suggests that a rise in total farm income of an exporting state or a rise in importing country's income leads to increased trade flows of most vegetables and fruits included in the analysis.

The magnitudes of the income elasticities are smaller than 1.0 suggesting that the trade flows are neither sensitive to changes in the productive capacity in exporting states nor to changes in the importers' disposable income in most cases. The income inelasticity in the exporting states may be due to their excess production capacity and domestic export promotion programs. ${ }^{3}$ The income

${ }^{3}$ Due to the lack of comparable data and the scope of this paper, we do not consider the export promotion programs of the U.S. states. 
inelasticity in importing countries may be due to the fact that vegetables and fruits are essentially necessities. In general, the extent of the income inelasticity is greater in the importing countries.

Populations in receiving countries are a significant factor enhancing trade flows. The importing country's population is an indication of its import market size and its absorption capacity. Its estimated coefficient sign is consistently positive and significant at 5\% level in most cases. In contrast, for most cases, population in exporting states is seen as a factor resisting vegetable and fruit export flows due to the competing domestic consumption needs. Thus, a rise in population of an exporting state leads to reduced commodity outflows. This is because vegetables and fruits are seen as consumption necessity goods, and the increases in the exporting state population would lead to increases in to the state vegetable and fruit consumption needs. The coefficient sign is negative and significant in the majority of the crops examined in our study. The findings seem to be consistent with results in Kalbasi (2001), Coulibaly (2006), and Agostino et al. (2007). However, in a few commodities such as cucumbers and gherkins, cabbages, the estimated population coefficients of the exporting states are positive. This suggests that an increase in an exporting state's population leads to increase trade flows of the respective crops. The positive coefficient signs of the exporting states' population may be viewed as commodity-specific and reflecting production scale and less domestic absorption effect. Hilbun (2006) also found a positive sign of the population coefficients of the exporting countries for aggregate agricultural goods.

The exchange rates are defined as changes in the prices of importing countries' currencies in terms of U.S. Dollars. An appreciation of an importing countries' currency (depreciation of an exporting country's currency) makes the exporting country's product cheaper and increases trade flows. In contrast, a depreciation of an importing country's currency decreases trade flows. However, the empirical results are inconclusive since our findings show that the estimated coefficients are weak and their significance is commodity specific.

\section{(2) The Effects of Free Trade Variables, Border, and Distance}

The gravity model includes factors aiding or resisting trade. The dummy variables representing the APEC, NAFTA, and EU regional economic groups are introduced to determine whether the formation of the common market in Asia under APEC, North America under NAFTA, and the European integration under EU common market enhances vegetable and fruit trade flows. The free trade 
variables were included in alternative models to avoid multicolliearity problems. An additional regional dummy variable was included to determine whether the Southeast region of the United States is a significant origin of trade in vegetables and fruits. Thus, four specifications (SP) for each crop are estimated.

The majority of coefficients on the NAFTA, EU and APEC dummy variables are positive and significant at the $1 \%$ level. These estimates show that the formation of the NAFTA, EU, and APEC enhances vegetable and fruit trade flows significantly in contributing to gross trade creation for the commodities in the analysis. Furthermore, it is interesting to note that the magnitude of the estimated coefficients on the APEC is much greater than that of the EU, suggesting that the APEC countries are significant destinations of U.S. states' vegetable trade flows than are EU countries. The border dummy variable indicates that countries with common borders traded more than countries geographically separated. However, the border dummy was deleted from our analysis to avoid perfect multicollinearity with the NAFTA dummy variable.

The theory of spatial equilibrium suggests that quantity of traded commodity varies inversely with distance. The estimated coefficients on distance are negative in most cases. However the degree of significance varies by commodity and time period. This suggests that the trade pattern in most vegetable and fruit trade flows is determined by distance. In a few models, the results suggest that distance is not significant and no longer a trade impairment factors as it used to be due to the increased means of communication and transportation (see Karemera et al. (1999) for more details).

\section{(3) The Effect of Seasonality and Other Factors}

Commodities of vegetable and fruit are considerably seasonal. Thus, in all of vegetable and fruit models, we include dummy variables to identify the impact of seasonality in the trade. However, all of our models failed to identify seasonal effects, except the models of soybean which exhibit significant trade seasonality. The lack of significant seasonality can be explained by the nature of data used. Data is dominated by cross section units with size reaching 123 and time series of 6 years for most commodities. Thus, the time effects are not estimable due to the lack of degree of freedom.

\section{(4) The Southeast Region}

The Southeast region (SER) was included to identify significance of the exports. 
The models suggest that the SER is a significant exporter of the following commodities: Soybeans, Tomatoes, and Cabbages frozen vegetables, Strawberries and Cabbages, and marginally Beans. South Carolina as a sole exporter was not a significant competitor in the world vegetable trade except in the Soybeans market (the insignificant results are not included but are available from authors upon request). This finding is consistent with the 1997 Census data showing soybeans as one of the four major commodities originating from South Carolina. However the region SER markedly influences vegetable trade flows from those states to world countries.

\section{(5) Comparison across Commodities}

An analysis of the impacts of economic groupings on specific commodity trade reveal that vegetables (Frozen (HS 0710)); peas (810); soybeans (120100) and cabbages (70490) show positive and significant results with the magnitudes of the coefficients greater than 1.0 or close to 1.0 for the APEC dummy variable. The magnitudes and the significance suggest that APEC is a significant destination for these commodities. NAFTA dummy variable has a positive and significant sign in most models. Furthermore, the magnitudes of the NAFTA dummy variable coefficients are greater than those for the EU dummy variables. This finding also suggests that gross trade creation under NAFTA is greater than gross trade creation in EU for the above vegetable and fruit trade flows.

\section{Conclusion}

The gravity model has been used to evaluate bilateral trade flows of aggregate commodity between pairs of states and countries. A common shortcoming of most gravity models is that the models are derived and applied mainly to aggregate commodity trade flows. This study demonstrates that the gravity models can be effectively modified to identify the determinants of single commodity trade flows and perform comparative static of the effects of various factors affecting the single commodity trade flows.

We apply the model to trade between U.S. states and world countries using nine vegetable commodities and a period ranging from 1996 to 2002. Our modified gravity equation shows that the included factors affecting trade flows have expected signs and are consistent in most cases with results from aggregate trade flow models. In general, we found the significant positive gross trade creation 
effects of NAFTA and APEC that are greater than the EU gross trade creation effects. The Pacific Rim region is found to be a significant destination for many vegetables and fruits from U.S. states.

Gravity factors such as state's farm income and importer's purchasing power are significant determinants of trade flows of most vegetables. Vegetables and fruits are essentially staple commodities. Thus, the results show that increases in population in receiving countries lead to increased imports while increases in population in sending states lead to decreased commodity exports for the large majority of the commodities included in the analysis.

Comparable data of various types of export promotion programs and import restriction policies are not readily available for all countries. Their effects on vegetable exports would provide a fruitful agenda for future research.

\section{Acknowledgement}

The authors wish to thank participants at the Seminar Series at South Carolina State University College of Business. Their constructive comments and suggestions improved the quality of the paper. Kermit Rose provided valued technical assistance and computer programming for the paper. Won Koo, Viceola Sykes, and Harun Adongo read earlier drafts of the manuscript. Financial support from the CSREES and 1890 Research is gratefully acknowledged. The usual disclaimer applies.

Received 28 April 2008, Revised 8 June 2008, Accepted 29 August 2008 


\section{Appendix}

Table A1. List of Exporting State and Destination Countries in the Vegetable and Fruit Trade

\begin{tabular}{|c|c|c|c|}
\hline Exporting State & Export Port/Point & Importing Country & Import Port/Point \\
\hline Alabama & Montgomery & Afghanistan & Kabul \\
\hline \multirow[t]{2}{*}{ Alaska } & Anchorage & Anguilla & Blowing Point \\
\hline & & Antiqua & \\
\hline Arizona & Phoenix & Barbuda & Antiqua and Barbuda \\
\hline Arkansas & Little Rock & Argentina & Buenos Aires \\
\hline California & Los Angeles & Aruba & Oranjestad \\
\hline Colorado & Denver & Australia & Sydney \\
\hline Connecticut & Hartford & Bahamas & Nassau \\
\hline Delaware & Dover & Bahrain & Al Manamah \\
\hline District of Columbia & Washington & Bangladesh & Dhaka \\
\hline Florida & Miami & Barbados & Barbados \\
\hline Georgia & Atlanta & Belgium & Brussels \\
\hline Hawaii & Honolulu & Belize & Belize \\
\hline Idaho & Boise City & Benin & Porto-Novo \\
\hline Illinois & Chicago & Bermuda & Bermuda \\
\hline Indiana & Indianapolis & Brazil & Sao Free \\
\hline Iowa & Des Moines & Brazil & Sao Paulo \\
\hline Kansas & Topeka & Brunei & Brunei \\
\hline Kentucky & Frankfort & Burma & Sittwe \\
\hline Louisiana & New Orleans & Canada & Edmonton \\
\hline Maine & Augusta & Canada & Montreal \\
\hline Maryland & Baltimore & Canada & Vancouver \\
\hline Massachusetts & Boston & Canada & Winnipeg \\
\hline Michigan & Detroit & Canada & Edmonton \\
\hline Minnesota & Minneapolis & Cayman Islands & Grand Cayman \\
\hline Mississippi & Jackson & Chile & Santiago \\
\hline Missouri & Jackson & China & Shanghai \\
\hline Nebraska & Lincoln & China & Shanghai \\
\hline Nevada & Carson City & Colombia & Bogotá \\
\hline New Hampshire & Plymouth & Costa Rica & San Jose \\
\hline New Jersey & Trenton & Cyprus & Nicosia \\
\hline New Mexico & Albuquerque & Czech Republic & Prague \\
\hline New York & New York & Denmark & Copenhagen \\
\hline North Carolina & Charlotte & Dominica & Dominica \\
\hline North Dakota & Bismarck & Dominican Rep & Santo Domingo \\
\hline Ohio & Columbus & Ecuador & Quito \\
\hline Oklahoma & Tulsa & Egypt & Cairo \\
\hline Oregon & Portland & El Salvador & San Salvador \\
\hline Pennsylvania & Pittsburgh & Estonia & Tallinn \\
\hline South Carolina & Columbia & Fiji & Nandi \\
\hline South Dakota & Pierre & Finland & Helsinki \\
\hline Tennessee & Nashville & France & Paris \\
\hline Texas & Houston & French Guiana & Cayenne \\
\hline Utah & Salt Lake City & French Polynesia & Tahiti \\
\hline
\end{tabular}


Table A1. List of Exporting State and Destination Countries in the Vegetable and Fruit Trade(continued)

\begin{tabular}{|c|c|c|c|}
\hline Virginia & Norfolk & Germany & Berlin \\
\hline Washington & Seattle & Greece & Athens \\
\hline Wisconsin & Milwaukee & Guatemala & Guatemala \\
\hline \multirow[t]{41}{*}{ Wyoming } & Cheyenne & Guyana & Georgetown \\
\hline & & Haiti & Port-au-Prince \\
\hline & & Hawaii & Honolulu \\
\hline & & Honduras & Tegucigalpa \\
\hline & & Hong Kong & Hong Kong \\
\hline & & Hungary & Budapest \\
\hline & & Iceland & Reykjavik \\
\hline & & India & New Delhi \\
\hline & & Indonesia & Djakarta \\
\hline & & Ireland & Dublin \\
\hline & & Israel & Tel Aviv \\
\hline & & Israel & Jerusalem \\
\hline & & Italy & Rome \\
\hline & & Jamaica & Kingston \\
\hline & & Japan & Tokyo \\
\hline & & Jordan & Aqaba \\
\hline & & Kenya & Nairobi \\
\hline & & Korean Republic & Seoul \\
\hline & & Kuwait & Kuwait \\
\hline & & Latvia & Riga \\
\hline & & Lebanon & Beirut \\
\hline & & Liberia & Monrovia \\
\hline & & Luxembourg & Luxembourg \\
\hline & & Malaysia & Sibu \\
\hline & & Malaysia & Kuala Lumpur \\
\hline & & Malaysia & Brunei \\
\hline & & Mali & Timbuktu \\
\hline & & Martinique & Fort-de-France \\
\hline & & Mexico & Monterrey \\
\hline & & Micronesia & Aderew \\
\hline & & Namibia & Windhoek \\
\hline & & Netherlands & Rotterdam \\
\hline & & Netherlands & Amsterdam \\
\hline & & New Zeland & Auckland \\
\hline & & New Zeland & Auckland \\
\hline & & Nicaragua & Managua \\
\hline & & Nigeria & Lagos \\
\hline & & North Korea & Pyongyang \\
\hline & & Norway & Oslo \\
\hline & & Oman & Muscat \\
\hline & & Pakistan & Rawalpindi \\
\hline
\end{tabular}


Table A2. Commodity Level Trade Data (Harmonized System Codes)

\begin{tabular}{lll}
\hline Commodity: & 710 & Vegetables (Uncooked or cooked) Frozen \\
Commodity: & 070110 & Potatoes (Seeds, fresh, or chilled) \\
Commodity: & $070200:$ & Tomatoes (Fresh, chilled) \\
Commodities: & $070490:$ & Cabbages \\
Commodity: & $070810:$ & Peas \\
Commodity: & $070820:$ & Beans \\
Commodity: & 120100, & Soybeans. \\
Commodity: & $081010 ;$ & Strawberries, Fresh \\
Commodities: & $200110:$ & Cucumbers and Gherkins \\
& & \\
\hline
\end{tabular}

Table A3. List of Countries Engaged in Regional Economic Groups

1. APEC members: Australia, Canada, Chine, Hong Kong, Indonesia, Japan, Malaysia, Mexico, New Zeeland, Philippines, Singapore, South Korea, Thailand, Taiwan, and the United States.

2. EU (15) countries: Austria, Belgium-Luxemburg, Denmark, France, Finland, Germany, Greece, Italy, Ireland, Netherlands, Norway, Portugal, Spain, Sweden, and United Kingdom. 3. NAFTA: U.S., Canada, and Mexico

4. SER: Florida, Georgia, North Carolina, and South Carolina 
Table A4. Gravity Equation Estimates of Determinants of Vegetables and Fruit Trade between U.S. States and World Countries, by Commodity Code

\begin{tabular}{|c|c|c|c|c|c|c|c|c|c|c|c|c|}
\hline \multirow[t]{2}{*}{ Commodity Code } & \multicolumn{4}{|l|}{710} & \multicolumn{4}{|l|}{70110} & \multicolumn{4}{|l|}{70200} \\
\hline & $S P 1$ & $S P 2$ & $\overline{S P 3}$ & SP4 & $S P 1$ & $S P 2$ & $S P 3$ & $S P 4$ & $S P 1$ & $S P 2$ & SP3 & $\overline{S P 4}$ \\
\hline State's farm Income & $(8.7)^{\mathrm{a}}$ & $(3.46)^{\mathrm{a}}$ & $(8.3)^{\mathrm{a}}$ & $(8.3)^{\mathrm{a}}$ & $(-1.6)^{\mathrm{c}}$ & $(2.19)^{\mathrm{b}}$ & $(2.17)^{\mathrm{b}}$ & $(2.17)^{\mathrm{b}}$ & $(2.02)^{\mathrm{b}}$ & $(-0.12)$ & $(-0.05)$ & $(0.05)$ \\
\hline Importer's income & $(3.01)^{\mathrm{a}}$ & $(3.46)^{\mathrm{a}}$ & $(3.71)^{\mathrm{a}}$ & $(3.71)^{\mathrm{a}}$ & $(2.24)^{b}$ & $(2.31)^{\mathrm{b}}$ & $(-0.47)$ & $(-0.47)$ & $(3.19)^{\mathrm{a}}$ & $(3.53)^{\mathrm{a}}$ & $(3.16)^{\mathrm{a}}$ & $(3.16)^{\mathrm{a}}$ \\
\hline \multirow[t]{2}{*}{ Distance } & -0.096 & -0.012 & -0.001 & -0.0093 & 0.172 & 0.314 & 0.32 & 0.32 & -0.215 & 0.03 & -0.053 & -0.053 \\
\hline & $(1.64)^{\mathrm{c}}$ & $(-0.23)$ & $(-0.02)$ & $(-0.02)$ & $(1.57)^{\mathrm{c}}$ & $(3.32)^{\mathrm{a}}$ & $(-3.74)^{\mathrm{a}}$ & $(3.74)^{\mathrm{a}}$ & $(-2.15)^{\mathrm{b}}$ & $(0.33)$ & $(-0.52)$ & $(-0.52)$ \\
\hline \multirow[t]{2}{*}{ Importer's Population } & 0.221 & 0.229 & 0.145 & 0.145 & 0.024 & 0.031 & 0.02 & 0.02 & -0.103 & -0.056 & -0.077 & -0.077 \\
\hline & $(10.6)^{\mathrm{a}}$ & $(10.8)^{\mathrm{a}}$ & $(6.64)^{a}$ & $(6.64)^{\mathrm{a}}$ & $(0.62)$ & $(0.79)$ & $(0.54)$ & $(0.54)$ & $(-2.89)^{\mathrm{a}}$ & $(-1.52)^{\mathrm{c}}$ & $(-2.1) b$ & $(-2.1) b$ \\
\hline \multirow{2}{*}{$\begin{array}{l}\text { Exchange Rate } \\
\text { changes }\end{array}$} & -0.034 & -0.042 & -0.062 & -0.062 & 0.059 & 0.056 & 0.028 & 0.028 & 0.118 & 0.075 & 0.095 & 0.095 \\
\hline & $(-2.15)^{b}$ & $(-2.64)^{\mathrm{b}}$ & $(4.01)^{\mathrm{a}}$ & $(-4.01)^{\mathrm{a}}$ & $(1.41)$ & (1.29) & $(0.67)$ & $(0.67)$ & $(2.65)^{\mathrm{b}}$ & $(1.6)^{\mathrm{c}}$ & $(2.05)^{\mathrm{b}}$ & $(2.05)^{\mathrm{b}}$ \\
\hline SER & 0.412 & & & & 0.48 & & & & 1.152 & & & \\
\hline \multirow[t]{2}{*}{$\mathbf{E U}$} & & & & -0.352 & & & & 0.216 & & & & -0.218 \\
\hline & & & & $(-3.6)^{\mathrm{a}}$ & & & & $(0.57)$ & & & & $(-0.88)$ \\
\hline \multirow[t]{2}{*}{ Quarter 1} & -0.038 & -0.031 & -0.063 & -0.064 & 0.125 & 0.134 & 0.189 & 0.189 & -0.37 & -0.268 & -0.283 & -0.283 \\
\hline & $(-0.44)$ & $(-0.35)$ & $(-0.77)$ & $(-0.77)$ & $(-0.21)$ & $(-0.62)$ & $(-0.89)$ & $(0.89)$ & $(1.68) \mathrm{c}$ & $(-1.17)$ & $(-1.24)$ & $(-1.24)$ \\
\hline \multirow[t]{2}{*}{ Quarter 2} & 0.051 & 0.054 & 0.029 & 0.029 & -0.214 & -0.219 & -0.274 & -0.274 & 0.146 & 0.224 & 0.214 & 0.214 \\
\hline & $(-0.58)$ & $(-0.61)$ & $(-0.35)$ & $(0.35)$ & $(-0.99)$ & $(-0.84)$ & $(-1.28)$ & $(-1.28)$ & $(-0.67)$ & $(-1.01)$ & $(-0.96)$ & $(0.96)$ \\
\hline \multirow[t]{2}{*}{ Quarter 3} & -0.072 & -0.067 & -0.081 & -0.081 & 0.085 & 0.07 & 0.072 & 0.071 & 0.438 & 0.494 & 0.546 & 0.545 \\
\hline & $(-0.82)$ & $(-0.76)$ & $(-0.96)$ & $(-0.96)$ & $(-0.38)$ & $(-0.32)$ & $(-0.32)$ & $(0.32)$ & $(1.97) b$ & $(2.15)^{\mathrm{b}}$ & $(-2.37)^{\mathrm{b}}$ & $(2.37)^{\mathrm{b}}$ \\
\hline F-Statistics & $36.62^{\mathrm{a}}$ & $33.28^{\mathrm{a}}$ & $40.11^{\mathrm{a}}$ & $68.01^{\mathrm{a}}$ & $4.93^{\mathrm{b}}$ & $4.59^{\mathrm{b}}$ & $5.25^{\mathrm{b}}$ & $5.25^{\mathrm{b}}$ & $17.22^{\mathrm{a}}$ & $16.63^{\mathrm{a}}$ & $21.02^{\mathrm{a}}$ & $15.84^{\mathrm{a}}$ \\
\hline R-square & 0.1176 & 0.1176 & 0.116 & 0.214 & 0.1279 & 0.1201 & 0.147 & 0.147 & 0.3254 & 0.3395 & 0.3705 & 0.3286 \\
\hline
\end{tabular}


Table A4. Gravity Equation Estimates of Determinants of Vegetables and Fruit Trade between U.S. States and World Countries, by Commodity Code(continued)

\begin{tabular}{|c|c|c|c|c|c|c|c|c|c|c|c|c|}
\hline \multirow[t]{2}{*}{ Commodity Code } & \multicolumn{4}{|l|}{70820} & \multicolumn{4}{|l|}{81010} & \multicolumn{4}{|l|}{70490} \\
\hline & $S P 1$ & $S P 2$ & SP3 & SP4 & $S P 1$ & $S P 2$ & SP3 & SP4 & SPI & $S P 2$ & SP3 & SP4 \\
\hline \multirow[t]{2}{*}{ State's farm Income } & 0.247 & 0.149 & 0.154 & 0.154 & 0.251 & 0.268 & 0.225 & 0.225 & -0.158 & -0.103 & -0.209 & -0.2097 \\
\hline & $(2.48)^{b}$ & $(1.65)^{\mathrm{c}}$ & $(1.72)^{\mathrm{c}}$ & $(1.72)^{\mathrm{c}}$ & $(8.7)^{\mathrm{a}}$ & $(9.35)^{\mathrm{a}}$ & $(8.3)^{\mathrm{a}}$ & $(8.30)^{\mathrm{a}}$ & $(-1.54)^{c}$ & $(-1.01)$ & $(2.27)^{\mathrm{b}}$ & $(-2.27)^{b}$ \\
\hline \multirow[t]{2}{*}{ Importer's income } & 0.095 & 0.092 & 0.097 & 0.097 & 0.029 & 0.033 & 0.034 & 0.034 & -0.17 & -0.025 & 0.016 & 0.016 \\
\hline & $(3.06)^{\mathrm{a}}$ & $(2.95)^{\mathrm{a}}$ & $(3.13)^{\mathrm{a}}$ & $(3.13)^{\mathrm{a}}$ & $(3.01)^{\mathrm{a}}$ & $(3.46)^{\mathrm{a}}$ & $(3.71)^{\mathrm{a}}$ & $(3.71)^{\mathrm{a}}$ & $(-0.68)$ & $(-0.98)$ & $(-0.61)$ & $(0.61)$ \\
\hline \multirow[t]{2}{*}{ Distance } & -0.261 & -0.622 & -0.56 & -0.56 & -0.096 & -0.012 & -0.001 & -0.009 & -0.064 & 0.203 & 0.171 & 0.171 \\
\hline & $(-1.18)$ & $(4.14)^{\mathrm{a}}$ & $(3.69)^{\mathrm{a}}$ & $(-3.69)^{\mathrm{a}}$ & $(-1.64)^{c}$ & $(-0.23)$ & $(-0.02)$ & $(-0.02)$ & $(-0.39)$ & $(-1.47)$ & $(-1.44)$ & (1.44) \\
\hline \multirow[t]{2}{*}{ State's Population } & -0.047 & 0.022 & 0.023 & 0.025 & -0.228 & -0.244 & -0.224 & -0.224 & 0.422 & 0.403 & 0.558 & 0.558 \\
\hline & $(-0.68)$ & $(0.35)$ & $(0.4)$ & $(0.062)$ & $(-10.18)^{a}$ & $(-11.0) \mathrm{a}$ & $(-10.7)^{a}$ & $(-10.7)^{a}$ & $(5.63)^{\mathrm{a}}$ & $(5.35)^{\mathrm{a}}$ & $(9.07)^{\mathrm{a}}$ & $(8.07)^{\mathrm{a}}$ \\
\hline \multirow[t]{2}{*}{ Importer's Population } & 0.0315 & 0.072 & 0.139 & 0.136 & 0.221 & 0.229 & 0.145 & 0.145 & 0.141 & 0.224 & 0.074 & 0.074 \\
\hline & $(0.37)$ & $(0.35)$ & $(1.51)^{\mathrm{c}}$ & $(1.51)^{\mathrm{c}}$ & $(10.56)^{\mathrm{a}}$ & $(10.7)^{\mathrm{a}}$ & $(6.64)^{\mathrm{a}}$ & $(6.64)^{\mathrm{a}}$ & $(2.36)^{b}$ & $(3.66)^{\mathrm{a}}$ & $(1.35)$ & $(1.35)$ \\
\hline \multirow[t]{2}{*}{ Exchange Rate changes } & -0.064 & -0.065 & -0.055 & -0.0547 & -0.034 & -0.042 & -0.063 & -0.062 & 0.242 & 0.194 & 0.056 & 0.056 \\
\hline & $(-1.29)$ & $(-1.31)$ & $(-1.08)$ & $(-1.08)$ & $(2.15)^{\mathrm{b}}$ & $(2.64)^{\mathrm{b}}$ & $(4.01)^{\mathrm{a}}$ & $(-4.01)^{\mathrm{a}}$ & $(4.43)^{\mathrm{a}}$ & $(3.47)^{\mathrm{a}}$ & $(-1.11)$ & (1.11) \\
\hline \multirow[t]{2}{*}{ SER } & -0.895 & & & & 0.412 & & & & 1.303 & & & \\
\hline & $(2.23)^{\mathrm{a}}$ & & & & $(3.79)^{\mathrm{a}}$ & & & & $(3.34)^{\mathrm{a}}$ & & & \\
\hline \multirow[t]{2}{*}{ NAFTA } & & -2.881 & & & & -0.854 & & & & -0.746 & & \\
\hline & & $(1.82)^{b}$ & & & & $(-2.18)^{\mathrm{a}}$ & & & & $(-1.28)$ & & \\
\hline \multirow[t]{2}{*}{ APEC } & & & -0.632 & & & & 1.415 & & & & 1.933 & \\
\hline & & & $(-1.77)^{c}$ & & & & $(15.62)^{\mathrm{a}}$ & & & & $(9.37)^{\mathrm{a}}$ & \\
\hline \multirow[t]{2}{*}{$\boldsymbol{E} \boldsymbol{U}$} & & & & 0.343 & & & & -0.3525 & & & & $-0.681 b$ \\
\hline & & & & (1.13) & & & & $(-3.6)^{\mathrm{a}}$ & & & & $(-2.62)^{b}$ \\
\hline \multirow[t]{2}{*}{ Quarter 1} & 0.003 & 0.006 & 0.019 & 0.019 & -0.034 & -0.031 & -0.064 & -0.064 & 0.034 & 0.009 & -0.031 & -0.031 \\
\hline & $(-0.01)$ & $(-0.02)$ & $(-0.07)$ & (0.07) & $(-0.44)$ & $(-0.35)$ & $(-0.77)$ & $(-0.77)$ & $(-0.13)$ & $(-0.03)$ & $(-0.13)$ & -0.13 \\
\hline \multirow[t]{2}{*}{ Quarter 2} & -0.183 & -0.192 & -0.196 & -0.196 & 0.051 & 0.054 & 0.029 & 0.028 & 0.033 & 0.004 & 0.024 & 0.024 \\
\hline & $(-0.68)$ & $(-0.71)$ & $(-0.73)$ & $(-0.73)$ & $(-0.58)$ & $(-0.61)$ & $(-0.35)$ & $(0.35)$ & $(-0.13)$ & -0.01 & $(-0.11)$ & 0.11 \\
\hline \multirow[t]{2}{*}{ Quarter 3} & -0.209 & -0.254 & -0.287 & -0.286 & -0.072 & -0.067 & -0.081 & -0.081 & 0.111 & 0.089 & 0.38 & 0.38 \\
\hline & $(-0.79)$ & $(-0.96)$ & $(-1.08)$ & $(-1.08)$ & $(-0.82)$ & $(-0.76)$ & $(-0.96)$ & $(-0.96)$ & $(-0.44)$ & $(-0.35)$ & $(1.65) \mathrm{c}$ & $(1.65) \mathrm{c}$ \\
\hline F-Statistics & $5.25^{b}$ & $5.4^{b}$ & $5.45^{b}$ & $5.07^{b}$ & $36.62^{a}$ & $33.28^{\mathrm{a}}$ & $37.72^{a}$ & $68.01^{a}$ & $10.07^{\mathrm{a}}$ & $9.14^{\mathrm{a}}$ & $11.2^{\mathrm{a}}$ & $22.56^{\mathrm{a}}$ \\
\hline R-square & 0.1736 & 0.1925 & 0.1789 & 0.183 & 0.1176 & 0.1176 & 0.1206 & 0.214 & 0.1641 & 0.1641 & 0.1793 & 0.3264 \\
\hline
\end{tabular}


Table A4. Gravity Equation Estimates of Determinants of Vegetables and Fruit Trade between U.S. States and World Countries, by Commodity Code (continued)

\begin{tabular}{|c|c|c|c|c|c|c|c|c|c|c|c|c|}
\hline Commodity Code & 200110 & & & & 70810 & & & & 120100 & & & \\
\hline & $S P 1$ & $S P 2$ & $\overline{S P 3}$ & SP4 & $S P 1$ & $S P 2$ & $\overline{S P 3}$ & SP4 & SP1 & $S P 2$ & $\overline{S P 3}$ & SP4 \\
\hline \multirow{2}{*}{ State's farm Income } & 0.035 & 0.179 & 0.123 & 0.123 & 0.607 & 0.631 & 0.629 & 0.629 & 0.448 & 0.447 & 0.453 & 0.452 \\
\hline & $(-0.33)$ & $(1.83)^{\mathrm{c}}$ & $(-1.29)$ & (1.29) & $(3.92)^{\mathrm{a}}$ & $(4.16)^{\mathrm{a}}$ & $(4.14)^{\mathrm{a}}$ & $(4.14)^{\mathrm{a}}$ & $(8.45)^{\mathrm{a}}$ & $(8.31)^{\mathrm{a}}$ & $(8.48)^{\mathrm{a}}$ & $(8.48)^{\mathrm{a}}$ \\
\hline \multirow[t]{2}{*}{ Importer's income } & 0.067 & 0.066 & 0.072 & 0.073 & 0.099 & 0.098 & 0.093 & 0.093 & -0.059 & -0.068 & -0.042 & -0.042 \\
\hline & $(4.59)^{\mathrm{a}}$ & $(4.4)^{\mathrm{a}}$ & $(4.99)^{\mathrm{a}}$ & $(4.99)^{\mathrm{a}}$ & $(2.17)^{\mathrm{b}}$ & $(2.05) \mathrm{b}^{\mathrm{a}}$ & $(1.94)^{\mathrm{b}}$ & $(1.94)^{\mathrm{a}}$ & $(3.35)^{\mathrm{a}}$ & $(3.62)^{\mathrm{a}}$ & $(2.34)^{b}$ & $(-3.34)^{\mathrm{a}}$ \\
\hline \multirow[t]{2}{*}{ Distance } & -0.062 & 0.175 & 0.191 & 0.19 & 0.286 & 0.301 & 0.298 & 0.298 & -0.838 & -0.28 & -0.705 & -0.704 \\
\hline & $(-0.64)$ & $(1.93)^{\mathrm{b}}$ & $(2.28)^{\mathrm{b}}$ & $(2.28)^{\mathrm{b}}$ & $(-1.25)$ & $(-0.97)$ & $(-1.31)$ & $(1.31)$ & $(6.8)^{\mathrm{a}}$ & $(1.82)^{\mathrm{c}}$ & $(5.76)^{\mathrm{a}}$ & $(-5.78)^{\mathrm{a}}$ \\
\hline \multirow[t]{2}{*}{ State's Population } & 0.297 & 0.371 & 0.398 & 0.398 & -0.46 & -0.45 & -0.467 & -0.467 & 0.205 & 0.101 & 0.112 & 0.112 \\
\hline & $(3.74)^{\mathrm{a}}$ & $(4.82)^{\mathrm{a}}$ & $(5.3)^{\mathrm{a}}$ & $(5.3)^{\mathrm{a}}$ & $(-2.83)^{\mathrm{a}}$ & $(-2.73)^{\mathrm{a}}$ & $(-2.85)^{\mathrm{a}}$ & $(-2.85)^{\mathrm{a}}$ & $(2.35)^{\mathrm{b}}$ & $(1.36)$ & $(1.52)^{\mathrm{c}}$ & $(1.52)^{\mathrm{c}}$ \\
\hline \multirow[t]{2}{*}{ Importer's Population } & 0.268 & 0.238 & 0.132 & 0.131 & -0.088 & -0.079 & -0.097 & -0.097 & 0.286 & 0.219 & 0.437 & 0.436 \\
\hline & $(6.65)^{\mathrm{a}}$ & $(5.41)^{\mathrm{a}}$ & $(2.96)^{\mathrm{a}}$ & $(2.96)^{\mathrm{a}}$ & $(-1.09)$ & $(-0.88)$ & $(-1.15)$ & $(-1.15)$ & $(5.81)^{\mathrm{a}}$ & $(4.14)^{\mathrm{a}}$ & $(8.18)^{\mathrm{a}}$ & $(8.18)^{\mathrm{a}}$ \\
\hline \multirow[t]{2}{*}{ Exchange Rate changes } & 0.028 & 0.028 & 0.036 & 0.036 & -0.025 & -0.026 & -0.015 & -0.015 & 0.086 & 0.119 & 0.088 & 0.087 \\
\hline & $(-1.11)$ & $(-1.07)$ & $(-1.43)$ & $(1.43)$ & $(-0.43)$ & $(-0.45)$ & $(-0.25)$ & $(-0.25)$ & $(3.02)^{\mathrm{a}}$ & $(4.01)^{\mathrm{a}}$ & $(3.05)^{\mathrm{a}}$ & $(3.05)^{\mathrm{a}}$ \\
\hline \multirow[t]{2}{*}{ SER } & 0.923 & & & & 0.232 & & & & 4.324 & & & \\
\hline & $(3.71)^{\mathrm{a}}$ & & & & $(-0.66)$ & & & & $(8.11)^{\mathrm{a}}$ & & & \\
\hline \multirow[t]{2}{*}{ NAFTA } & & 0.637 & & & & -0.286 & & & & 1.776 & & \\
\hline & & $(1.90)^{\mathrm{c}}$ & & & & $(-0.14)$ & & & & $(4.54)^{\mathrm{a}}$ & & \\
\hline \multirow[t]{2}{*}{ APEC } & & & 0.915 & & & & -0.017 & & & & -0.745 & \\
\hline & & & $(6.02)^{\mathrm{a}}$ & & & & $(-0.06)$ & & & & $(5.37)^{\mathrm{a}}$ & \\
\hline \multirow[t]{2}{*}{$\boldsymbol{E} \boldsymbol{U}$} & & & & -0.447 & & & & -0.1819 & & & & 0.397 \\
\hline & & & & $(-2.7)^{\mathrm{a}}$ & & & & $(-0.63)$ & & & & $(2.84)^{\mathrm{a}}$ \\
\hline \multirow[t]{2}{*}{ Quarter 1} & -0.019 & -0.03 & -0.019 & -0.0198 & -0.521 & -0.544 & -0.541 & -0.542 & -0.444 & -0.437 & -0.389 & -0.389 \\
\hline & $(-0.14)$ & $(-0.22)$ & $(-0.14)$ & $(-0.14)$ & $(-1.54)$ & $(-1.62)$ & $(-1.61)$ & $(-1.61)$ & (2.88)a & (2.81)a & (2.51)a & $(-2.51) b$ \\
\hline \multirow[t]{2}{*}{ Quarter 2} & -0.144 & -0.137 & -0.169 & -0.168 & -0.057 & -0.057 & 0.629 & -0.050 & -0.977 & -0.979 & -0.872 & -0.872 \\
\hline & $(-1.03)$ & $(-0.98)$ & $(-1.23)$ & $(-1.23)$ & $(-0.18)$ & $(-0.17)$ & $(-0.15)$ & $(-0.15)$ & (5.82)a & (5.78)a & (5.14)a & $(-5.14) \mathrm{a}$ \\
\hline \multirow[t]{2}{*}{ Quarter 3} & -0.081 & -0.084 & -0.105 & -0.105 & -0.382 & -0.378 & -0.374 & -0.374 & -0.809 & -0.799 & -0.712 & -0.711 \\
\hline & $(-0.57)$ & $(-0.59)$ & $(-0.76)$ & $(-0.76)$ & $(-1.13)$ & $(-1.12)$ & $(-1.11)$ & $(-1.11)$ & (4.62)a & (4.53)a & (4.04)a & $(-4.04)$ \\
\hline$\overline{F-S t a t i s t i c s}$ & $15.4^{\mathrm{a}}$ & $14.02^{\mathrm{a}}$ & $16.59^{a}$ & $18.76^{\mathrm{a}}$ & $7.75^{b}$ & $7.03^{b}$ & $7.81^{b}$ & $7.06^{b}$ & $22.00^{\mathrm{a}}$ & $20.06^{\mathrm{a}}$ & $26.88^{\mathrm{a}}$ & $22.49^{a}$ \\
\hline R-square & 0.1586 & 0.1589 & 0.1688 & 0.2019 & 0.3145 & 0.3152 & 0.3162 & 0.3161 & 0.0803 & 0.0805 & 0.0963 & 0.0894 \\
\hline
\end{tabular}

Note: a Significant at $1 \%$, b Significant at $5 \%$, c Significant at $10 \%$. Asymptotic t-ratios are in parentheses. 


\section{References}

Agostino, M. R., Aiello, F., Cardamone, P.(2007), http://www.fondazionemasi.it/ UploadDoc/182.

Anderson, J. S.(1979), "A Theoretical Foundation for the Gravity Equation", American Economic Review, 69(1), pp. 106-115.

Anderson, J. S., Wincoop, v. E.(2003), "Gravity with Gravitas: A Solution to the Border Puzzle”, American Economic Review, 93(1), pp. 170-192.

Bergstrand, J. H.(1985), "The Gravity Equation in International Trade: Some Microeconomic Foundations and Empirical Evidence", Review of Economics and Statistics, August, pp. 481-8.

Bergstrand, J. H.(1989), "The Generalized Gravity Equation, Monopolistic Competition, and the Factor Proportions Theory in International Trade", Review of Economics and Statistics, February, pp. 143-53.

Bergstrand, J. H.(1990), "The Heckscher-Ohlin-Samuelson Model, the Linder Hypothesis, and the Determinants of Bilateral Intra-Industry Trade", The Economic Journal, December, pp. 1216-29.

Burfisher, M. E., Sherman R., Thierfelder, K.(2001), "The Impact of NAFTA on the United States", Journal of Economic Perspectives, 15, pp. 125-44.

Coughlin, C.C., Wall, H.J.(2002), "NAFTA and the Changing Pattern of State Exports", Federal Reserve Bank of St. Louis, Working Paper 2000-029B, Research Division St. Louis, MO.

Coulibaly, S.(2006), http://www.cepii.fr/anglaisgraph/communications/pdf/09100206.

Deardorff, V A.(1998), "Determinants of Bilateral Trade: Does Gravity Work in a Neoclassical World?" in Frankel, Jeffrey A., (Ed.), The Regionalization of the World Economy. Chicago: U of Chicago Press.

Frankel, J., E. Stein, E., Shang-jin, W.(1995), “Trading Blocs and the Americas: The Natural, the Unnatural, and the Supper-Natural", Journal of Development Economics, 47(1), pp. 61-95.

Gould, M. D.(1998), "Has NAFTA Changed North American Trade?" Federal Reserve Bank of Dallas Economic Review, First Quarter, pp. 12-23.

Hilbun, B. M. (2006), http://etd.lsu.edu/docs/available/etd-04192006-102931/ unrestricted/Hilbun_thesis.pdf.

Hummels, D., Levinsohn, J.(1995), "Monopolistic Competition and International Trade: Reconsidering the Evidence", Review of Economics and Statistics, Aug., pp. 799-836

KALBASI(2001), http://www.ecomod.net/conferences/ecomod2001/papers_web/ KALBASI.pdf.

Karemera, D., Ojah, K.(1998), "An Industrial Analysis of Trade Creation and Trade Diversion Effects of NAFTA", Journal of Economic Integration, 13, pp. 400-425.

Karemera, D., Smith, I. W. K. Ojah, K., and Cole, A. J.(1999), "A Gravity Model Analysis of the Benefits of Economics Integration in the Pacific Rim”, Journal of Economic 
Integration, 14(3), pp. 347-367.

Koo, W. W., Karemera, D., Taylor, R.(1993), "A Gravity Model Analysis of Meat Trade Policies", Agricultural Economics, 10, pp. 81-88.

Krueger, A. O.(1999a), "Are Preferential Trading Agreements Trade-Liberalizing or Protectionists", Journal of Economic Perspectives, 139(4), pp. 105-24.

Krueger, A.O.(1999b), "Trade Creation, and Trade Diversion under NAFTA", National Bureau of Economic Research, Cambridge, MA, Working Paper no.729.

Linneman, H.(1966), "An Econometric Study of International Trade Flow", Amsterdam: North-Holland Publishing.

MacAleer, M.(1985), "Specification tests for separate models: A survey", In M. L. King and D. E. A. Gires (Ed.) Specification Analysis in the Linear Model, London: Routledge and Kegan Paul.

Markusen, R. J.(1986), "Explaining the Volume of Trade: An Eclectic Approach", American Economic Review, December, pp. 1002-11.

McClatchy, D., Cahill, S., Surry, Y.(1989), "Exchange Rates and Multilateral Free Trade in Agriculture", Canadian Journal of Agricultural Economics, CJAE, Vol. 37, p. 993.

National Agricultural Statistics Service (NASS) U.S. Department of Agriculture/ Economic Research Service: various issues.

United States Department of Commerce Highlights of U. S. Exports and Imports, Various issues.

Wall H.J.(2000), "NAFTA and the Geography of North American Trade", Federal Reserve Bank of St.Louis, Working Paper 2000-017B Research Division. St. Louis, MO. 